\title{
Antibiotic bead pouch dressing
}

\author{
Dale A Classen MD FRCSC \\ Assistant Professor, Division of Plastic Surgery, Department of Surgery, Royal \\ University Hospital, Saskatoon, Saskatchewan
}

DA Classen. Antibiotic bead pouch dressing. Can J Plast Surg 1996;4(4):199-202.

The antibiotic bead pouch is a dressing consisting of antibiotic laden

polymethylmethacrylate (PMMA) beads placed in a wound, which is covered by a porous membrane (Opsite). This paper outlines the method, rationale and results of the use of this dressing technique for extensive wounds before definitive wound closure. A case series review of 15 consecutive patients with a variety of soft tissue wounds that were managed with an antibiotic bead pouch dressing is presented. The method of dressing has been a useful and successful adjunct to the management of extensive infected and contaminated wounds.

Key Words: Dressing, Polymethylmethacrylate beads, Wound

Pansements pour sachet de granules antibiotiques

RÉSUMÉ : Le sachet de granules antibiotiques est un pansement composé de granules de polyméthylméthacrylate imprégné d'antibiotique que l'on place dans la plaie et que l'on recouvre d'une pellicule poreuse (Opsite). Cet article résume la méthode, sa raison d'être et les résultats de son emploi dans les cas de plaies importantes, avant leur fermeture définitive. On présente ici le compte-rendu d'une série de 15 cas consécutifs de patients porteurs de diverses plaies des tissus mous traitées au moyen de pansements antibiotiques. Cette méthode de pansement a été utile et efficace en traitement d'appoint pour le traitement des plaies très infectées et contaminées.

The antibiotic bead pouch is a dressing consisting of antibiotic laden polymethylmethacrylate (PMMA) beads placed in a wound, which is covered by a porous membrane (Opsite, Smith \& Nephew). It provides a closed, moist environment for the wound. Thus, in the antibiotic-hematoma-wound environment, all structures are protected from desiccation and high concentrations of antibiotic are maintained throughout the hematoma surrounding the wound. The antibiotic bead pouch technique has been described for the management of extremity compound fractures by Henry et al $(1,2)$ and Ostermann et al (3). This paper describes the treatment of 15 consecutive patients with a variety of soft tissue wounds managed with an antibiotic bead pouch dressing before definitive wound closure. Seven patients had infected wounds, either soft tissue or bone, before institution of the bead pouch dressing. Eight patients did not have wound infections but were either at risk for significant infections or had wounds with exposed tendon, bone or orthopedic hardware. Successful infection-free wound healing was achieved in all cases. 


\section{PATIENT SERIES}

The antibiotic bead pouch dressing was used in 15 patients over 25 months. Seven patients had wounds that were clinically infected before institution of the antibiotic bead pouch (Table 1). Of these, one patient had chronic osteomyelitis, three had acute infection of bone and surrounding soft tissue, and the remaining three had severe soft tissue infections only. Five patients had a single organism cultured from their wound (patients 1,2,3,4,7); two patients had multiple organisms cultured from their wounds (patients 5,6).

Of the patients with infections, one patient had one debridement and one bead pouch application before wound closure. The remaining six patients had between two and five operative irrigations, debridements and antibiotic bead pouch dressings before definitive wound coverage. The antibiotic bead pouch dressing remained in place for as short as one day to as long as six days between bead pouch changes or definitive wound closure.

Eight of the 15 patients in this series did not have wound infections before the use of an antibiotic bead pouch dressing (Table 2). All eight patients had wounds that were at significant risk of becoming colonized, and possibly infected, before definitive wound coverage. All wounds had a significant amount of exposed tendon, bone or orthopedic hardware. The antibiotic bead pouch provided a sterile, moist wound environment, protecting soft tissues and bone from desiccation and possibly preventing orthopedic hardware from becoming colonized or contaminated. Six of the eight patients had one irrigation, debridement and antibiotic bead pouch dressing before definitive wound closure. Two patients had two antibiotic bead pouch dressings before wound closure.

\section{TECHNIQUE}

Management of all these wounds took place in the operating room and consisted of thorough debridement of all necrotic and contaminated tissue. Debridement was followed by high pressure pulse saline lavage irrigation. Tissue cultures were taken before placement of the antibiotic beads. A chain of premanufactured gentamicinimpregnated PMMA 10 mm diameter beads (Septopal, E Merck, Darmstadht, Germany) were placed in the wound. Friar's balsam (Stanley Pharmaceuticals) was applied to the surrounding skin to adhere the porous polyethylene dressing. A completely watertight seal of the wound was obtained. A $10 \mathrm{~mm}$ Jackson-Pratt (JP) drain (Baxter Healthcare, Illinois) was placed in the wound to collect overflow drainage. Suction was not applied to the drain. The antibiotic bead pouch was left intact until the patient returned to the operating room for either further irrigation, debridement and antibiotic bead pouch dressing or definitive wound coverage. Between operative procedures, the antibiotic bead pouch dressing was left intact. No wound care was required. The antibiotic bead pouch temporarily closed the wound, providing a closed moist wound environment while at the same time delivering high levels of antibiotics to the wound locally. 
TABLE 1: Patient profiles: Infected wounds

\begin{tabular}{|c|c|c|c|c|c|c|c|}
\hline Patient & $\begin{array}{c}\text { Age } \\
\text { (years) }\end{array}$ & Injury & Organism & $\begin{array}{c}\text { Number of } \\
\text { treatments* }\end{array}$ & $\begin{array}{l}\text { Type of } \\
\text { surgical } \\
\text { closure }\end{array}$ & Outcome & $\begin{array}{c}\text { Follow- } \\
\text { up } \\
\text { (months) }\end{array}$ \\
\hline 1 & 60 & \begin{tabular}{|l|} 
Pyoderm \\
gangrenosum \\
over achilles \\
tendon \\
\end{tabular} & $\begin{array}{l}\text { Staphlococcus } \\
\text { aureus }\end{array}$ & 2 & $\begin{array}{l}\text { Scapular } \\
\text { free flap }\end{array}$ & Healed & 9 \\
\hline 2 & 50 & \begin{tabular}{|l|} 
Diabetic \\
dorsal foot \\
infection \\
with \\
osteomyelitis \\
\end{tabular} & $\begin{array}{l}\text { Staphlococcus } \\
\text { epidermidis }\end{array}$ & 2 & $\begin{array}{l}\text { Split } \\
\text { thickness } \\
\text { skin graft }\end{array}$ & Healed & 5 \\
\hline 3 & 13 & \begin{tabular}{|l|} 
Compound \\
tibia/fib \\
fracture with \\
osteomyelitis \\
tibia
\end{tabular} & \begin{tabular}{|} 
Pseudomonas \\
aeruginosa
\end{tabular} & 3 & $\begin{array}{l}\text { Lattisimus } \\
\text { muscle } \\
\text { free flap }\end{array}$ & Healed & 14 \\
\hline 4 & 72 & \begin{tabular}{|l|} 
Marjolins \\
ulcer in \\
chronic \\
osteomyelitis \\
tibia \\
\end{tabular} & S aureus & 1 & $\begin{array}{l}\text { Lattisimus } \\
\text { muscle } \\
\text { free flap }\end{array}$ & Healed & 5 \\
\hline 5 & 16 & $\begin{array}{l}\text { Compound } \\
\text { fracture } \\
\text { tibia/fib }\end{array}$ & \begin{tabular}{|l|} 
Bacteriodes \\
fragilis, \\
Streptococcus, \\
Enterococcus, \\
Enterobacteriaceae \\
\end{tabular} & 5 & $\begin{array}{l}\text { Split } \\
\text { thickness } \\
\text { skin graft }\end{array}$ & Healed & 4 \\
\hline 6 & 15 & $\begin{array}{l}\text { Compound } \\
\text { calcaneus } \\
\text { fracture }\end{array}$ & $\begin{array}{l}\text { B fragilis, } \\
\text { Escherichia coli, } \\
\text { Streptococcus }\end{array}$ & 3 & \begin{tabular}{|l} 
Serratus \\
muscle \\
free flap
\end{tabular} & Healed & 4 \\
\hline 7 & 58 & $\begin{array}{l}\text { Diabetic } \\
\text { dorsal hand } \\
\text { infection }\end{array}$ & S aureus & 5 & $\begin{array}{l}\text { Reverse } \\
\text { radial } \\
\text { forearm } \\
\text { flap }\end{array}$ & Healed & 4 \\
\hline
\end{tabular}

*Irrigation, surgical debridements and bead pouch dressings 
TABLE 2: Patient profiles: Noninfected wounds

\begin{tabular}{|c|c|c|c|c|c|c|}
\hline Patient & $\begin{array}{c}\text { Age } \\
\text { (years) }\end{array}$ & Injury & $\begin{array}{l}\text { Number of } \\
\text { treatments* }\end{array}$ & $\begin{array}{l}\text { Method of } \\
\text { surgical } \\
\text { closure }\end{array}$ & Outcome & $\begin{array}{l}\text { Follow-up } \\
\text { (months) }\end{array}$ \\
\hline 1 & 12 & $\begin{array}{l}\text { Soft tissue } \\
\text { degloving injury } \\
\text { hip }\end{array}$ & 1 & $\begin{array}{l}\text { Lattisimus } \\
\text { muscle free } \\
\text { flap }\end{array}$ & Healed & 24 \\
\hline 2 & 16 & $\begin{array}{l}\text { Auger } \\
\text { amputation, foot } \\
\text { (compound } \\
\text { fractures) }\end{array}$ & 2 & $\begin{array}{l}\text { Rectus } \\
\text { muscle free } \\
\text { flap }\end{array}$ & Healed & 25 \\
\hline 3 & 58 & $\begin{array}{l}\text { Compound } \\
\text { fractures forearm }\end{array}$ & 1 & $\begin{array}{l}\text { Split } \\
\text { thickness } \\
\text { skin graft }\end{array}$ & Healed & 12 \\
\hline 4 & 20 & $\begin{array}{l}\text { Gunshot wound } \\
\text { hand (compound } \\
\text { fractures) }\end{array}$ & 1 & $\begin{array}{l}\text { Lateral arm } \\
\text { free flap }\end{array}$ & Healed & 16 \\
\hline 5 & 52 & $\begin{array}{l}\text { Venous stasis } \\
\text { ulcer leg }\end{array}$ & 1 & $\begin{array}{l}\text { Split } \\
\text { thickness } \\
\text { skin graft }\end{array}$ & Healed & 10 \\
\hline 6 & 15 & $\begin{array}{l}\text { Degloving injury } \\
\text { foot (compound } \\
\text { fractures) }\end{array}$ & 1 & $\begin{array}{l}\text { Lattisimus } \\
\text { muscle free } \\
\text { flap }\end{array}$ & Healed & 10 \\
\hline 7 & 35 & $\begin{array}{l}\text { Hay bailer injury } \\
\text { arm soft tissue } \\
\text { avulsion }\end{array}$ & 1 & $\begin{array}{l}\text { Scapular free } \\
\text { flap }\end{array}$ & Healed & 9 \\
\hline 8 & 42 & $\begin{array}{l}\text { Soft tissue } \\
\text { avulsion forearm }\end{array}$ & 2 & $\begin{array}{l}\text { Scapular free } \\
\text { flap }\end{array}$ & Healed & 3 \\
\hline
\end{tabular}

*Irrigation, surgical debridements and bead pouch dressings

\section{CLINICAL CASE}

A 16-year-old boy caught his right foot in a farm auger (Table 2, patient 2). $\mathrm{He}$ suffered incomplete amputation of his toes with a dorsal soft tissue loss. After wound debridement exposed metatarsals and K-wire were evident. A string of gentamicin beads and a JP drain was placed in the wound (Figure 1A). This was covered with an Opsite dressing (Figure 1B). Follow-up at 25 months demonstrated a well healed wound covered by a rectus muscle free flap and split thickness skin graft (Figure 1C). 


\section{OUTCOME}

Infected wounds were seen in seven patients; four wounds were closed with free tissue transfers (one scapular free flap, two latissimus muscle free flaps, one serratus muscle free flap), two with split thickness skin grafts and one with a reverse radial forearm flap. All patients healed uneventfully without complications in their acute postoperative period. There were no acute infections. Long term follow-up varied between 10 and 20 months. No patient had evidence of late infection at follow-up. In the eight patients without infection before institution of the antibiotic bead pouch, six wounds were closed with free tissue transfers (two latissimus muscle free flaps, one rectus muscle free flap, one lateral arm flap, two scapular free flap). Two wounds were closed with a skin graft. No infections occurred in either the acute postoperative period or in the follow-up period of between three and 25 months.

\section{DISCUSSION}

Antibiotic impregnated bone cement was first described for the prophylaxis and treatment of infected total hip arthroplasties by Bulcholz in 1970 (4). Klemm (2) subsequently devised the concept of pre-formed gentamicin-impregnated PMMA beads and inserting them into an infected bone or soft tissue cavity after debridement (2). Although many antibiotics have been used to impregnate PMMA beads, gentamicin, tobramycin and vancomycin are the most useful clinically because of their broad spectrum of coverage and physical characteristics that allow for their combination with and release from PMMA beads. The beads are commercially available in two sizes: $7 \mathrm{~mm}$ and $10 \mathrm{~mm}$ diameter with strands of 10,30 or 60 beads per chain. In this series of patients, $10 \mathrm{~mm}$ gentamicin beads were used; each bead contains $4.5 \mathrm{mg}$ of gentamicin. Usually 30 beads were placed in the wounds.

Administering antibiotics to a wound locally delivers much higher levels of antibiotic concentration to the wound than systemic administration. This is particularly important in wounds or tissues with poor vascularity, such as tendon and bone. One study demonstrated that the local antibiotic concentration was up to 200 times higher than could be achieved by systemic administration (5). Despite very high local levels of antibiotics, systemic serum and urine levels of antibiotics are low, thus minimizing any systemic toxicity (nephrotoxicity or ototoxicity) (6).

Antibiotic from PMMA beads leaches into the postoperative hematoma/seroma. Release of the antibiotic from the beads is most marked in the first $48 \mathrm{~h}$; however, antibiotic continues to be released for weeks (5). Animal studies have shown antibiotic concentrations persist six months or longer after bone implantation (7). Because the beads leach their antibiotic into the hematoma/seroma in the wound, it is important that the hematoma/seroma remain in the wound. This is achieved by covering the wound with an Opsite dressing. The hematoma should not be evacuated. The drain is placed in these wounds solely to allow any excess hematoma to be evacuated in an overflow fashion, preventing it from leaking under the Opsite. Suction is never applied to the drain. Various animal studies have demonstrated the efficacy of antibiotic-impregnated beads in preventing the establishment of infection in contaminated wounds (8-10). 

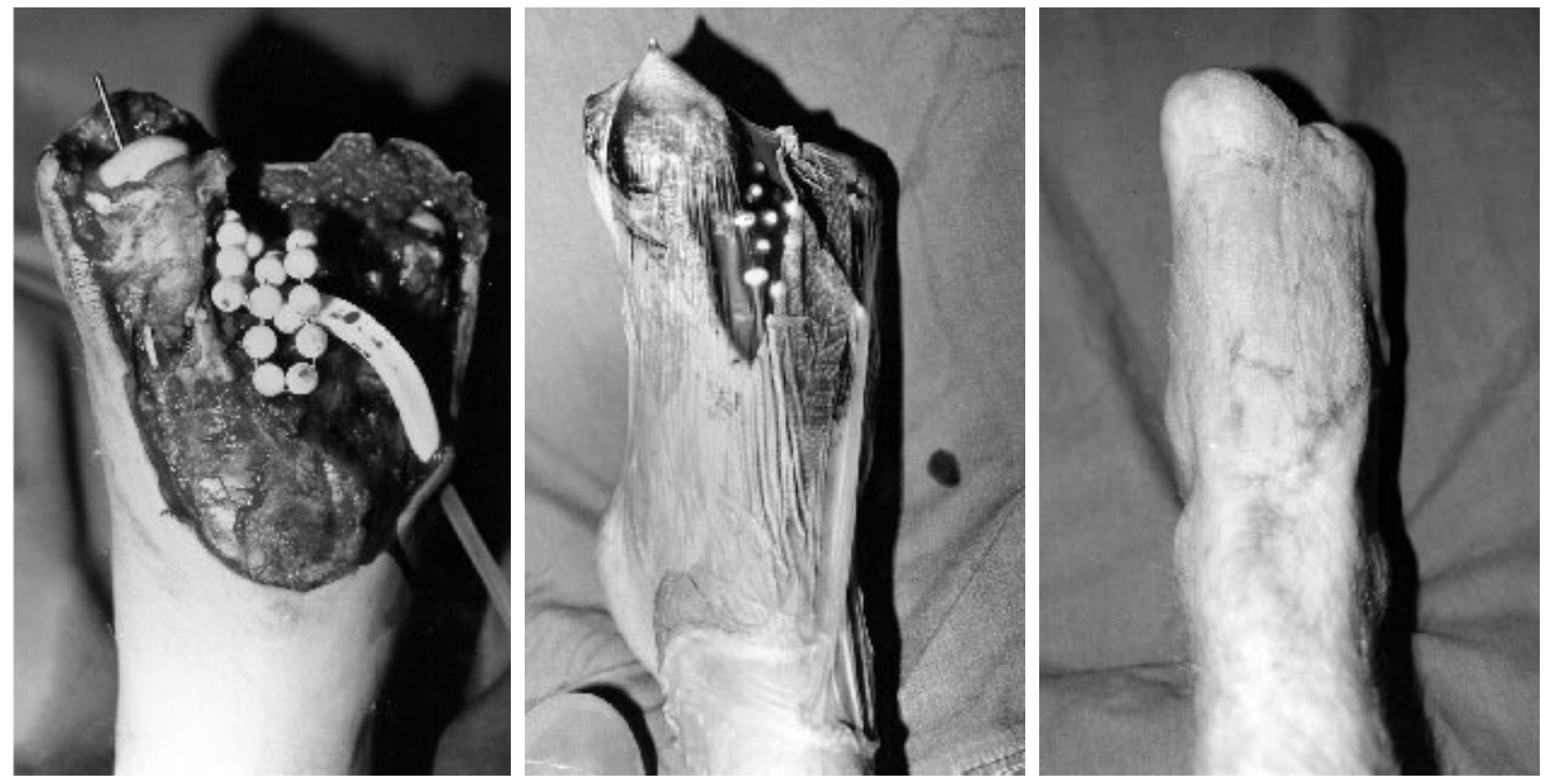

Figure 1) Left A A 16-year-old boy with incomplete amputation of toes with a dorsal soft tissue loss. A string of gentamicin beads and a Jackson-Pratt drain were placed in the wound after debridement. Centre B The wound was covered with an Opsite dressing to maintain a moist, closed environment. Right $\boldsymbol{C}$ At 25 months'follow-up the wound had healed, covered by a rectus muscle free flap and split thickness skin graft

Clinical studies have demonstrated a reduction in the incidence of early and late infections when an antibiotic bead pouch is used as a temporary dressing for compound extremity fractures (1-3). However, no prospective study demonstrates the efficacy of antibiotic beads in the prevention and treatment of soft tissue or bony infection.

A surgeon may elect to delay definitive wound closure for a variety of reasons, and while waiting for definitive wound closure, a wound may be managed in a variety of ways. It may be left open and dressed with a gauze dressing such as saline gauze, Xeroform (Sherwood Medical Industries), Sofra-tulle (Hoechst-Marion-Roussel), etc. Disadvantages of an open dressing technique are frequent, often painful dressing changes, dessication of tissues (particularly in exposed tendon or bone), and the potential for wound contamination either through saturated dressings or with each dressing change. This is of particular concern if there is exposed hardware or devascularized tissue. An alternative method of management is to close the wound temporarily. Closing the wound allows a moist wound environment to develop, advantageous to wound healing (11).

Placing antibiotic beads in a closed wound environment is a particularly useful adjunct in the management of a variety of soft tissue and bony wounds. The antibiotic bead pouch delivers a high level of antibiotics to the wound, much higher than systemic levels can achieve. This is particularly important for patients who have clinical wound infections, but it is also useful in patients with wounds which are at significant risk of 
developing an infection before definitive wound coverage. As well because the wound is sealed and closed, the potential for secondary colonization or infection of the wound is eliminated. After achieving a clean wound with surgical irrigation and debridement, it is important to maintain the cleanliness of the wound while waiting for definitive wound closure. The antibiotic bead pouch allows the surgeon to temporarily 'close' a wound without fear of infection or contamination. Despite often very extensive wounds, a closed sealed wound is relatively comfortable for the patient, and painful dressing changes are avoided. The moist wound environment allows for protection of vital structures and prevention of their desiccation, of great concern in cases with large areas of exposed tendon and bone. In some extensive wounds the dressing is very useful in promoting the growth of granulation tissue, which may be necessary before skin grafting can occur.

\section{SUMMARY}

The antibiotic bead pouch dressing is an excellent method for obtaining a closed moist wound environment while waiting for definitive wound coverage. In this series of 15 patients closing wounds with an antibiotic bead pouch allowed for management of the wounds in a unhurried manner. Successful wound healing was achieved in all patients without early or late complications, in particular no wound infections. Thorough surgical debridement and irrigation of the wound as well as provision of well vascularized tissue to these wounds (10 patients had free tissue transfers) contributed to the patients' successful healing. Although these wounds could certainly be managed by other methods of dressing before performing definitive wound closure, the antibiotic bead pouch dressing was a simple and effective method, providing a closed moist wound environment. This series of patients demonstrates an expanded role for antibioticimpregnated PMMA beads.

\section{REFERENCES}

1. Henry S, Ostermann P, Seligson D. The prophylactic use of antibiotic impregnated beads in open fractures. J Trauma 1990;30:1231-8.

2. Henry S, Ostermann P, Seligson D. The antibiotic bead pouch technique. Clin Orthop 1993;295:54-62.

3. Ostermann P, Henry S, Seligson D. The role of local antibiotic therapy in the management of compound fractures. Clin Orthop 1993;295:102-11.

4. Klemm K. Antibiotic bead chains. Clinical Orthop 1993;295:63-76.

5. Wahlig H, Dingeldein E, Berjmann R, Reuss K. The release of gentamicin from polymethylmethacrylate beads. J Bone Joint Surg 1978;60B:270-5.

6. Walenkamp G, Vree T, Van Rens T. Gentamicin - PMMA beads. Clin Orthop 1986;205:171-83.

7. Eckman J, Henry S, Maningo P, Seligson D. Wound and serum levels of tobramycinimpregnated polymethylmethacrylate beads in compound fractures. Clin Orthop 1988;237:213-5.

8. Chapman M, Hadley W. The effect of polymethymethacrylate and antibiotic combination on bacterial viability. J Bone Joint Surg 1976;58A:76-81. 
9. Fitzgerald R. Experimental osteomyelitis: Description of canine model and the role of depot administration of antibiotics in the prevention and treatment of sepsis. J Bone Joint Surg 1983;65A:371-80.

10. Seligson D, Mehta S, Voos K, et al. The use of antibiotic impregnated

polymethylmethacrylate beads to prevent the evolution of localized infection. J Orthop Trauma 1992;6:401-6.

11. Nickerson D, Freiberg A. Moisture-retentive dressings: A review of the current literature. Can J Plast Surg 1995;3:35-8. 